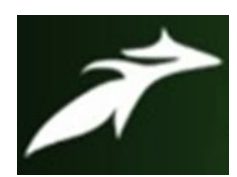

Heli S. Oza et al, International Journal of Advances in Agricultural Science and Technology,

Vol.8 Issue.3, March-2021, pg. 27-39

ISSN: 2348-1358

Impact Factor: 6.057

NAAS Rating: 3.77

\title{
Impact of Climate Condition on Flowering, Fruiting, Kernel and Nut-yield In Newly Added Potential Growing Areas of Cashewnut in India- A Review
}

\author{
Heli S. Oza; Hitesh Solanki \\ Department of Horticulture and Garden Management \\ USSC Gujarat University, Navrangpura, Ahmedabad \\ (E-mail: helioza4199@gmail.com; hasolanki@gujaratuniversity.ac.in)
} DOI: 10.47856/ijaast.2021.v08i3.003

\begin{abstract}
Cashew is now an important Horticulture plant for India and now India is exporting cashew at a good scale. Traditional Indian growing area comprises the parts of Karnataka, Maharashtra, Goa, West Bengal, Odisha, Andhra Pradesh and Tamil Nadu states. However, now new areas are coming up with good potential for cultivation such as Gujarat, Jharkhand, Chhattisgarh, Andaman and Nicobar island, North Earsten Hilly States. Cashew cultivars are recommended based on geographical distribution, climate, soil based on these flowering and fruiting time. Cashew nut yield and kernel weight can be different for different varieties and so on its quality with shelling can vary. Flowering and fruiting is greatly influenced by rain because it starts flowering after monsoon, which is greatly influenced by the onset and offset of Indian monsoon that India varies from state to state as India has north-east monsoon and south-west monsoon. Moreover, soil characteristics across India varies widely. Integrated effect of soil, rainfall and temperature drives the optimum growth of cashew trees, which resulted in the change in yield and quality of cashew nuts. The present review paper addresses many of these drivers and their impact on cashew produce in India.
\end{abstract}

Keywords: Cashew Cultivar, India, Climate, Geographical distribution, Morphology assessment

\subsection{Introduction}

Cashew (Anacardium occidentale L.) is a perennial tropical tree of the Anacardiaceae family. The cashew is an important crop for semi-arid agriculture, which contributes to the social and economical development of numerous world regions (Bezerra et al. 2007). Though, it is native to tropical America, the West Indies, Brazil and Peru, cashew is one of the most important crop in India because of significant profits from its exports. In India, cashews were first introduced by the Portuguese 500 years ago to Goa and then spread to other regions. The term "Cashew" has originated from the Brazilian name "acajaiba" and the Tupi name "a caju", which the Portuguese converted into "Caju" and is commonly known as "kaju" in India (Saroj et al. 2014). Despite its first purpose of introduction, presently cashew has been 


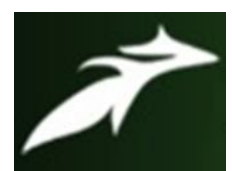

Heli S. Oza et al, International Journal of Advances in Agricultural Science and Technology, Vol.8 Issue.3, March-2021, pg. 27-39

ISSN: 2348-1358

Impact Factor: 6.057

NAAS Rating: 3.77

widely grown for its nuts to be used as food, medicine, and source of income in mainly tropical regions with the major coverage found in Brazil, India, Vietnam, Indonesia, and numerous countries in West and East Africa (Tola and Mazengia 2019).

India is the first country in the world to benefit from the international trade in cashew nuts in the early 20th century. Currently, cashews are planted on an area of 8.93 thousand hectares, which produces 6.95 thousand tons of cashew nuts per year (Bhat et al. 2010). Cashews are also known as wild goldmine (Dasmohapatra et al. 2013, Jayasankar et al. 2018). Commercial cultivation began in the early 1960s, and over time, cashews became a high value-added crop, earning the status of an export-oriented commodity, bringing significant money to the country.

World production of raw cashew nuts has also grown to 4.9 million tons in 2016, which was just 0.29 million tons in 1961 (Tola and Mazengia 2019). Cashew production is affected by variability of climatic factors (Balogoun et al. 2016). In recent years, considering the possibility of global climate change, an increasing emphasis on world food security and its regional impacts became a key issue for the scientific community (Mall et al. 2006). Under normal conditions, Crop growth, development, water use and yield are largely determined by the prevailing weather during the growing season. Any change from 'normal weather' has an effect over the crop production and cashew plantation is also not immune to these changes. This paper reviews the possible impact of climate change in Indian cashew growing regions.

\subsection{Geographical distribution}

Globally cashew growing regions are located between $28^{\circ} \mathrm{N}$ and $28^{\circ} \mathrm{S}$ (Salam and Peter 2010). In India, it grows along the entire coastal strip from $8^{\circ} \mathrm{N}$ to $28^{\circ} \mathrm{N}$. Major Indian traditional cashew growing regions are found in the states located along the west coast (Maharashtra, Goa, and Karnataka) and east coast (Tamil Nadu, Andhra Pradesh, Odisha, and West Bengal) in southern parts of India (Rejani et al. 2013, Polisetty et al. 2018). However, nowadays, cashews are spreading rapidly in the nontraditional regions such as Dharampur-Kaprada talukas of Gujarat (Shah et al. 2018, Ghadage et al. 2016). Malhotra et al. (2017) reported for the cashew plantation in Jharkhand, Chhattisgarh (Bastar district), North Eastern Hilly (NEH) states, Andaman and Nicobar islands, plains of Karnataka, North Eastern Hilly (NEH) states Meghalaya, Tripura, Manipur and Nagaland. Moreover, some parts of Assam and Mizoram are likely to cultivate on industrial bases. In the state of Gujarat, it is observed that cashew plantations are also being grown on a trial basis in the parts of Dang, Narmada and Tapi districts (Shah et al. 2018). Scattered new plantations were 


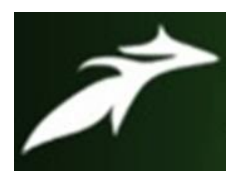

Heli S. Oza et al, International Journal of Advances in Agricultural Science and Technology, Vol.8 Issue.3, March-2021, pg. 27-39

ISSN: 2348-1358

Impact Factor: 6.057

NAAS Rating: 3.77

also observed in Saurashtra region (including Junagadh, Rajkot, Bhavnagar, Amreli and Surendranagar districts). Shah et al. (2018) have reported that considering the taste, whiteness and crunchiness of the produce, cashew from South Gujarat is superior as compared to cashew from Goa.

\subsection{Environmental and soil suitability}

In most cashew growing regions of the world, climate is characterized by high temperatures with low and irregular precipitation, providing insufficient water for plants over the larger part of the year (Bezerra et al. 2007).

\subsection{Dependence on climate and soil:}

The appearance of cashews is strongly influenced by the elevation of the place where they are being grown (Malhotra et al. 2017). Flowering time depends on the latitude, hence low temperatures at high altitudes adversely affect harvest. It is reported that the maximum altitude suitable for planting cashews depends on the latitude. Cashews were planted at an altitude of about $1000 \mathrm{~m}$, but in Assam, India, $250 \mathrm{~m}$ to the north, it was found that elevations above $700 \mathrm{~m}$ were not suitable for harvesting. This could be due to the fact that the lower temperature at higher altitude has an effect on the development of the cashew trees. Cashews are sunny trees that cannot tolerate excessive shade. The sunny period on the west coast of India averages more than 9 hours a day from December to May, while there is less sunshine in the southwest and Northwest from June to November. This variation in sunshine hours has an impact on the quality of cashew produce. The dependence of the growth of cashew plantation on the climate and soil parameters are shown in Figure 1.

It is observed that the region receiving rainfall below $300 \mathrm{~mm}$ per year is not suitable for growing the cashew, which results in the lower yield of cashew nuts. Loamy red \& lateritic soil, red \& black mixed soil, Alluvium derived soil, sandy loams \& loams, coastal sand and loamy \& silt loam are the types of soil that are best suitable for the healthy growth of cashew plantation.

Cashew trees are larger and yield more in deep, strongly weathered soils (Ngatunga 2001). Widiatmaka (2014) studies that $76 \%$ of cashew production variability is influenced by effective soil depth. Poorly drained soil, or soil with lower than $45 \mathrm{~cm}$ depth, is not suitable for better growth. Generally, well drained, red sandy loam and light coastal soil with high water holding capacity and rich in organic matter is preferred (Jena and Panda 2020). Desirable soil depth is $90 \mathrm{~cm}$ but $45-90 \mathrm{~cm}$ soil depth is also good (Rejani et al. 2013 ). All around, depleted soil is must to dodge water logging and root decay, with pH going from 5.8 


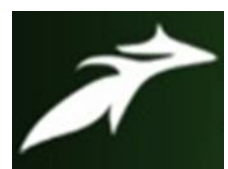

Heli S. Oza et al, International Journal of Advances in Agricultural Science and Technology, Vol.8 Issue.3, March-2021, pg. 27-39

ISSN: 2348-1358

Impact Factor: 6.057

NAAS Rating: 3.77

to 6.8 (Desai et al. 2014). According to Venugopal and Khader (1991) soil salinity higher than $2 \%$ is unsuitable for normal growth. Expected yield may exceed $1000 \mathrm{~kg}$ per hectare, if all the parameters influencing the growth are favorable.

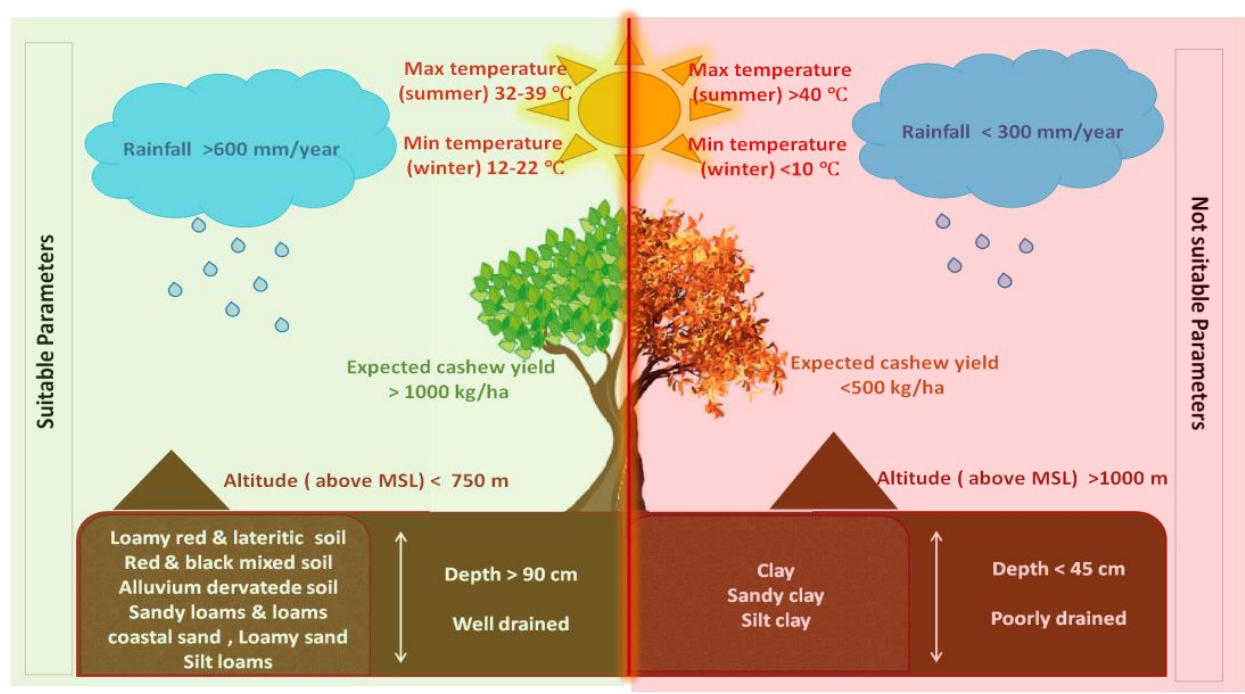

Figure 1: Suitability of climate and soil conditions for the growth of Cashew plantation (prepared from the data reported in Rejani et al. 2013)

Cashews tend to grow further south in response to sunlight in the northern hemisphere. The maximum daily temperature in the main cashew producing regions is found within $25{ }^{\circ} \mathrm{C}$ to $35{ }^{\circ} \mathrm{C}$. Bezerra et al. (2007) reported that the optimal temperature for cashew seed germination in Brazil is around $35^{\circ} \mathrm{C}$. Blooming cashews need a cool winter, particularly lower minimum surface air temperatures, ranging from $16{ }^{\circ} \mathrm{C}$ to $20{ }^{\circ} \mathrm{C}$, combined with humid nights. Onset of Indian monsoon varies from one region to another region. In the regions of Andhra Pradesh, Karnataka, North East Hilly regions, Goa and West Bengal onset of monsoon is observed in June. Maharashtra, Odisha, Chhattisgarh has onset of monsoon in mid June. Generally in Gujarat monsoon arrives at the end of June. Mostly monsoon season is around 4 months in India. As the onset of monsoon varies from state to state, variation in the offset is also observed from one state to another state located in different parts of India. Monsoon offset occurs at the end of October in Maharashtra, Goa, West Bengal, Chhattisgarh, Andhra Pradesh, Odisha and Karnataka. Monsoon offset observed for NEH is in Mid october and that for Gujarat is in the end of September. It is to be noted that Kerala, Tamilnadu and Andaman Nicobar have two monsoon. In these regions one South West Monsoon retreats from the area and Northeast monsoon gets established. These 


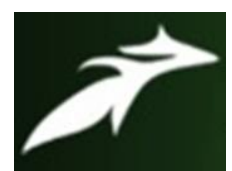

Heli S. Oza et al, International Journal of Advances in Agricultural Science and Technology, Vol.8 Issue.3, March-2021, pg. 27-39

ISSN: 2348-1358

Impact Factor: 6.057

NAAS Rating: 3.77

variations in monsoon onset, offset and associated rainy days vary widely within India, which also has an impact on the variation in the phenology of cashew trees and quality of the cashew produce.

Abnormal rains between November-December slow down the breeding stage of abnormal late flowering varieties. Moreover it was observed that cashews require a climate with a precisely defined minimum drying time of 4 to 5 months. A climate with a spell of 4 to 6 dry months and period along with monsoon period of 1,000 to 2,000 mm rainfall is suitable for commercial cashew cultivation (Malhotra et al. 2017). Widiatmaka (2014) observed that the number of dry months, which are strongly correlated with a level of productivity above $80 \%$, is 5 to 10 months.

Average rainfall distribution in the cashew region ranges from low rainfall ( 300 to $600 \mathrm{~mm}$ in Gujarat) to high rainfall (2700 to $3500 \mathrm{~mm}$ on the west coast and in the NEH regions). Little rainfall during the months of January to March increases the yield of cashew production. Heavy rains adversely affect the yield (Widiatmaka 2014), which leads to poor and early dropping of nuts. Light rain during flowering will not damage the blooms, but heavy rain during flowering will affect harvest. Coincidence of flowering with high rainfall or excess humidity leads to incidence of pests and diseases (Bhoomika and Rani 2018). Water deficits and changes from the optimal values of salinity and prevailing temperatures are the most likely environmental factors limiting the cashew production (Bezerra et al. 2007).

\subsection{Cultivar and Morphological assessment}

India is a very diverse country in terms of regional variations in land use/land cover variations and meteorological conditions. The state-wise variation in cashew production and cultivars are given in Table-1 (Desai et al. 2010 , Gajbhiye et al. 2018, Hanumanthappa et al. 2014, Muthu Kumar et al. 2011, Nayak et al. 2020, Saroj 2015 , Shah et al. 2018, Tripathy et al. 2015, Vikram at al. 2013)

Table-1: State-wise production and cultivars

\begin{tabular}{|c|c|c|}
\hline States & $\begin{array}{c}\text { Production } \\
(2014-15) \%\end{array}$ & Preferable cultivars \\
\hline Maharashtra & 31.3 & $\begin{array}{r}\text { Vengurla-I Vengurla-3, Vengurla-4, Vengurla-6, Vengurla-7 } \\
\text { and Vengurla-8. }\end{array}$ \\
\hline Andhra Pradesh & 13.3 & BPP-4, BPP-6 and BPP-8 \\
\hline
\end{tabular}




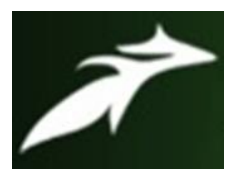

Heli S. Oza et al, International Journal of Advances in Agricultural Science and Technology, Vol.8 Issue.3, March-2021, pg. 27-39

ISSN: 2348-1358

Impact Factor: 6.057

NAAS Rating: 3.77

\begin{tabular}{|c|c|c|}
\hline Odisha & 11.4 & Bhubaneswar-I, BPP-8 and Dhana. \\
\hline Karnataka & 10.7 & $\begin{array}{l}\text { NRCC Sel-2, Bhaskara, Ullal-I, Ullal-3, Ullal-4, Vengurla-4, } \\
\text { Vengurla-7, } \\
\text { Madakkathara-2, Chintamani-1 and Chintamani-2. }\end{array}$ \\
\hline Kerala & 10.6 & $\begin{array}{c}\text { Madakkathara-I, Madakkathara-2, K-22-I, Kanaka, Dhana, } \\
\text { Priyanka, Amrutha and VRI-3. }\end{array}$ \\
\hline Tamil Nadu & 8.9 & VRI-1, VRI-3 and VRI H-1 \\
\hline Goa & 4.3 & $\begin{array}{c}\text { Goa-1, Goa-2, Vengurla-1, Vengurla-4, Vengurla-6 and } \\
\text { Vengurla-7. }\end{array}$ \\
\hline Gujarat & 3.3 & Vengurla-4, Vengurla-7 \\
\hline West Bengal & 1.7 & Jhargram-I, Bidhan Jhargram-2 and BPP-8 \\
\hline $\mathrm{NEH}$ & 4.4 & Ullal-3, Ullal-4, Vengurla-1, Vengurla-4 \\
\hline Chhattisgarh & & Vengurla-4, Indira kaju-1 \\
\hline
\end{tabular}

\subsection{Roots, leaves and canopy structure:}

Cashew is a perennial polygamous and male evergreen plant. Generally, the cashew tree is tall and widespread, with a height varying from 8 to $15 \mathrm{~m}$ and a crown span up to $20 \mathrm{~m}$ (Bezerra et al. 2007). Generally the estimated life of the cashew trees are around 50 to 60 years and start bearing fruit in their third to fifth year (Tola and Mazengia 2019). There are two types of cashew nut growth, respectively intensive and extensive. Cashews have an extensive lateral root system with a tap root that penetrate deep into the soil. Generally the cashew leaves are dark green at the top with opaque green in the beneath (Malhotra et al. 2017). Both sided smooth cashew leaves are glabrous, thick, leathery, oblong to obviate and alternately located on the branches (Kumar et al. 2012, Mog et al. 2018). Leaves have a blunt top and slightly tapered bottom. Size of the leaves is around 10 to $20 \mathrm{~cm}$ long and 5 to $10 \mathrm{~cm}$ wide, varying in a ratio of 1.8:1. Generally, stem length is observed between 0.5 to $1 \mathrm{~cm}$. Canopy-type of various hybrid or selection varieties, grown across India, are given in Figure-2 (Dasmohapatra et al. 2014, Malhotra 


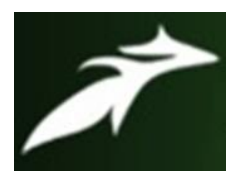

Heli S. Oza et al, International Journal of Advances in Agricultural Science and Technology,

Vol.8 Issue.3, March-2021, pg. 27-39

ISSN: 2348-1358

Impact Factor: 6.057

NAAS Rating: 3.77

et al. 2017). Canopy structures can be classified as compact, open, upright \& open, upright \& compact, spreading, semi-spreading and highly spreading (Salam et al. 2010).

\subsection{Flowering and fruiting:}

Cashew is considered as an andromonoecious species (Saroj et al. 2014). Cashew flowers are small with white or light green colour, which are turning pink when opened. The conical, pyramidal or irregular in shaped inflorescence of cashew is called terminal panicle (Dendena and Corsi 2014). It bears both male (staminate) and hermaphrodite (perfect) flowers in the same panicle due to which it is considered as an andromonoecious and cross pollinated species (Bhoomika et al. 2018; Sethi et al. 2020). Flowers and fruits are borne on the outer extremity of the canopy due to the production of flowers at the end of the new shoots (Janani et al. 2020). In general, seedling cashew plants start flowering in three to five years. However, grafted trees come to flowering within 3 years. Normally flowering starts after the emergence of new growth flush at the end of monsoon. Timing and duration flowering are strongly influenced by the prevalent temperature. Across India, regional differences were observed in the flowering time. Generally, variety-wise flowering and fruiting time extends from November of the year to the June of subsequent year (Figure-2).

\begin{tabular}{|c|c|c|c|c|c|c|c|c|c|c|c|c|c|c|c|c|c|}
\hline No. & Variety & Hybrid/selection & Canopy type & ż & प̆ & 胥 & 巳̊ํㄴ & $\sum^{\frac{1}{\pi}}$ & $\frac{2}{4}$ & $\sum^{\frac{\pi}{\pi}}$ & $\leqq$ & $\Xi$ & $\frac{a 0}{\vec{z}}$ & ๗ั & $\overleftarrow{\circlearrowleft}$ & Apple Colour & Juice $\%$ \\
\hline 1 & MADAKKATHARA - 1 & Selection & Compact & & & & & & & & & & & & & Yellow & 72 \\
\hline 2 & DHANA & Hybrid & Compact & & & & & & & & & & & & & Yellow & 72 \\
\hline 3 & $\mathrm{~K}-22-1$ & Selection-Kottarakkara22 & Compact & & & & & & & & & & & & & Red & 68 \\
\hline 4 & VENGURLA-4 & Midnapur RedxVetore56 & Open & & & & & & & & & & & & & Red & 76 \\
\hline 5 & VENGURLA-6 & Vetore-56 xVengurla-1 & Compact & & & & & & & & & & & & & Yellow & 85 \\
\hline 6 & VENGURLA-7 & Vengurla-3 x VRI-1 & Compact & & & & & & & & & & & & & Yellow & 86 \\
\hline 7 & BPP- 4 & Epurupalem selecion & Upright and open & & & & & & & & & & & & & Yellow & 60 \\
\hline 8 & BPP-6 & Selection & Upright and open & & & & & & & & & & & & & Yellow & 65 \\
\hline 9 & BPP-8 & T.NO $\times 1$ T.NO 40 & Upright and compact & & & & & & & & & & & & & Yellow & 66 \\
\hline 10 & VRI $(\mathrm{CW}) \mathrm{H} 1$ & Hybrid & Semi Spreading & & & & & & & & & & & & & Pink with yellow tinge & 77 \\
\hline 11 & ULLAL-3 & Variety & Highly Spreading & & & & & & & & & & & & & Pink Red & 75 \\
\hline 12 & ULLAL-4 & Variety & Spreading & & & & & & & & & & & & & Yellow & 70 \\
\hline 13 & GOA-1 & Selection from Balli-2 & Semi spreading & & & & & & & & & & & & & Yellow & 68 \\
\hline \multicolumn{5}{|c|}{ Flowering Time } & \multicolumn{6}{|c|}{ Fruiting Time } & & & & & & & \\
\hline
\end{tabular}

Figure -2. Variety-wise flowering, fruiting, apple colour and juice characteristics

By and large the anthesis is observed between 9 am to $2 \mathrm{pm}$ in India. Approximately 80 percent of the perfect flowers open between 10 am and 12 Noon. The peak period of dehiscence of anthers was observed between 9.30 to $11.30 \mathrm{am}$. Generally, rate of dehiscence was slightly higher on the sunny side of the tree as compared to that on the shady side (Malhotra et al. 2017, Saroj et al. 2014). Figure-2 also shows the description of canopy structure, apple colour and juice percentage for different hybrid/selection varieties grown across India. Cashew apple is generally still of minor economic 


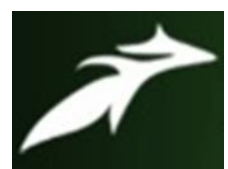

Heli S. Oza et al, International Journal of Advances in Agricultural Science and Technology, Vol.8 Issue.3, March-2021, pg. 27-39

ISSN: 2348-1358

Impact Factor: 6.057

NAAS Rating: 3.77

importance, however, cashew apple juice was found to contain the highest amount of vitamin $\mathrm{C}$ compared to some of the tropical fruits like pineapple, orange, grape, mango and lemon (Akinwale 2000).

The cashew fruit comprises a kidney-shaped nut and a pseudo-apple (Akinwale 2000). The whole cashew fruit consists of two parts: the bottom part (nuts) and the top part (falls fruit). The grey coloured nuts have kidney shaped achene with a dry one-seeded indehiscent fruit with the seed distinct from the fruit wall (Saroj et al. 2014). Nuts generally consist of epicarp, mesocarp, endocarp and a kernel wrapped by a peel (testa). The skin is smooth, corrosive, gray or greenish-gray, forms the epidermis. The spongy mesocarp is the thickest of the three layers. It has alveoli containing Cashew Nut Shell Liquid (CNSL), which is a sticky, gummy, corrosive oil rich in phenolic compounds (Gandhi et al. 2012, Akinhanmi et al. 2018). Endocarp consists of a hard, dense mass of sclerenchymatous cells (Saroj et al. 2014). These three layers form a thick crust, i.e. pericarp, and make up $45-50 \%$ of the pith. Nuts, the edible part, are made up of two cotyledons, which make up 20 to $22 \%$ of the nuts. Brown film (crust) covering the nuts make up about $5 \%$ by weight of the nuts.

Cashew apples were bred from artificial and hypertrophied pistils. The ratio of nuts to apples is usually 1:8. Bright apples are green, lavender or light green and turn green. When the apples are ripe, they turn red or yellow or faded. This is an indicator that the nuts can be harvested. Ripe apples have a peculiar smell. Ripe apples contain about 60$85 \%$ juice (Figure-2).

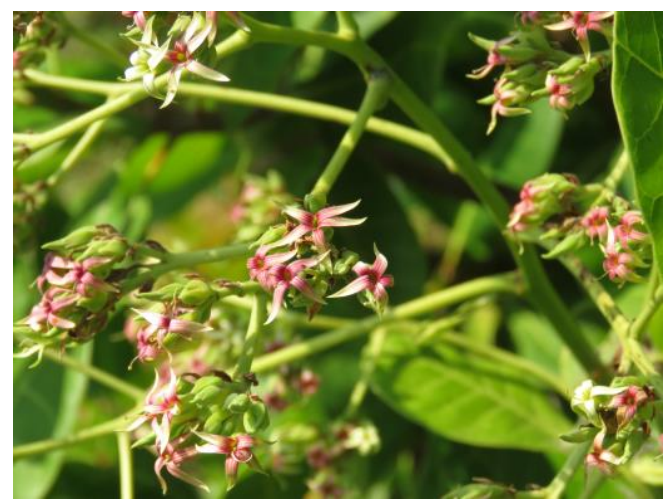

Fig: 3 Flowering in February 2020 at Dharampur in Valsad district of Gujarat, photograph courtesy to Dhruva Jani , student at Department of botany, Gujarat University

\subsection{Kernel and nut yields:}

The kernel of cashew nut is edible, economical and processed part (Sreenivas et al. 2016, Balasubramanian 2015). It has a wrinkled surface and is covered by a reddish brown as pink testa. The white coloured kernel is having high nutritional quality. The 


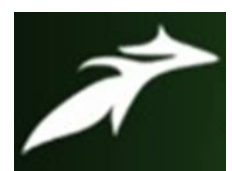

Heli S. Oza et al, International Journal of Advances in Agricultural Science and Technology, Vol.8 Issue.3, March-2021, pg. 27-39

ISSN: 2348-1358

Impact Factor: 6.057

NAAS Rating: 3.77

variety or growing conditions have an influence on kernel composition (Malhotra et al. 2017). Moreover, quality of yield also depends on the shelling operations. Shelling is the operation of removal of shells protecting the style of the kernels, which produce whole crack-free kernels. Only with a little care, one can produce an annual average of 50 to 75 $\mathrm{kg}$ of apples and nuts per tree, yielding up to $4 \mathrm{~kg}$ of cashew kernels (Ona et al., 2017). Figure-4 shows the variety-wise characteristics of cashew nuts and kernels. It is observed that the export grade of the produce is inversely proportional to the shelling percentage for the different varieties. Despite a lower nut weight of BPP-8 compared to Vengurla-7, per tree yield is higher for BPP-8. As observed from the figure, maximum yield is found for the BPP-8 variety, whereas Goa-1 has the lowest yield per tree. Despite a lower nut weight of BPP-8 compared to Vengurla-7, per tree yield is higher for BPP-8.
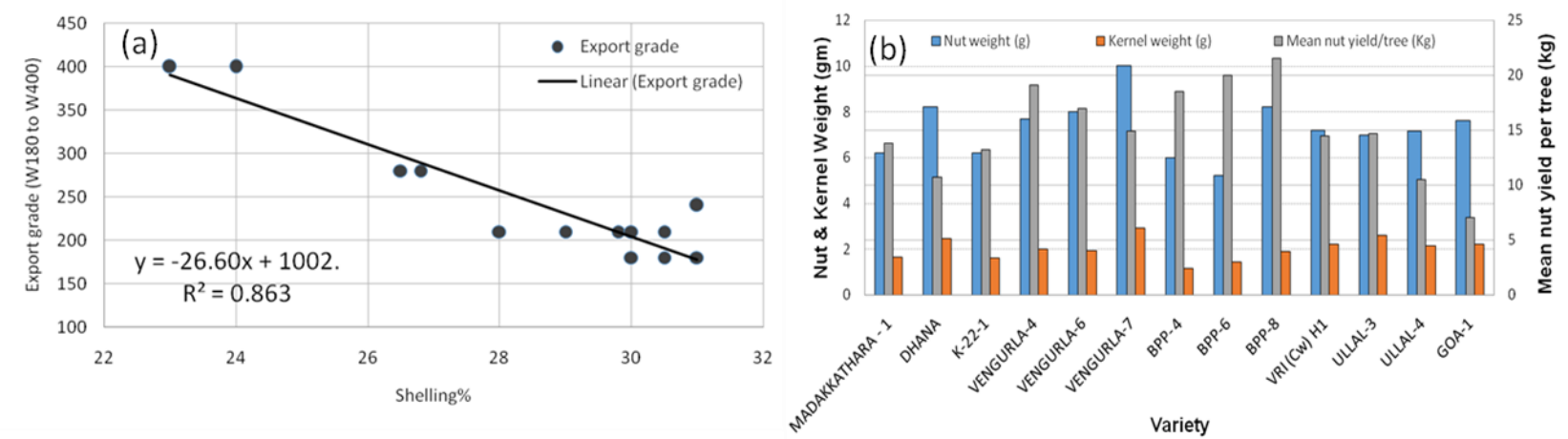

Figure 4. variety-wise characteristics of cashew nuts and kernels (a-The regression analysis performed using the data reported by Malhotra et al. (2017), Salam et al. (2010)

\subsection{Conclusion}

Cashew is one of the very important plants, which not only resist erosion it has tremendous commercial and medical value. In India, cashew areas are located mainly in southern and eastern parts but the growing region is now expanded in western parts also. As India is one of the most diverse country in terms of agro-climatic variability, cashew production is also varying from one region to another region. Moreover, regionto-region variation was observed in the quality of the produce. Analysis of the varietywise characteristics revealed that the quality of cashew nuts is significantly correlated with the percentage of shelling.

Out of the selected varieties, maximum yield is found for the BPP-8 (mainly in Andhra pradesh and Odisha) variety and lowest for Goa-1 (mainly in Goa) variety. Optimum values of the climatic parameters, which are a driving force for the variation in cashew 


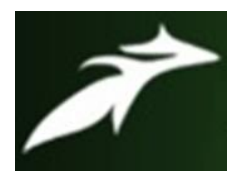

Heli S. Oza et al, International Journal of Advances in Agricultural Science and Technology, Vol.8 Issue.3, March-2021, pg. 27-39

ISSN: 2348-1358

Impact Factor: 6.057

NAAS Rating: 3.77

phenology, health and quality of produce are described in this paper. The review highlighted the possibility of expansion of cashew areas in the region, where they are presently being grown on an experimental basis. Moreover, review also brought out the fact that despite being rich in vitamin $\mathrm{C}$, cashew apple juice is not being produced on an operational basis. This is one of the potential produce from the cashew cultivation in India, which can help to boost the economy.

\section{Acknowledgement:}

We express our gratitude towards Dr. Archana Mankad, Head of the Botany Department, Gujarat University for kind encouragement and support to carry out the review. Corresponding author would like to acknowledge Ms. Dhruva Jani for making available photograph of cashew flowers and thankfully acknowledges her Parents for their kind support.

\section{References}

1. Akinwale, T. O., 2000. Cashew apple juice: its use in fortifying the nutritional quality of some tropical fruits. Eur Food Res. Technol., 211:205-207.

2. Akinhanmi, T. F., Atasie, V. N., \& Akintokun, P. O. (2008). Chemical composition and physicochemical properties of cashew nut (Anacardium occidentale) oil and cashew nut shell liquid. Journal of Agricultural, Food and Environmental Sciences, 2(1), 1-10.

3. Balasubramanian. D (2015) , CASHEW NUT PROCESSING in CASHEW PRODUCTION TECHNOLOGY.(Eds: Nayak,M.G; Sajeev,M.V)Director ICARDirectorate of Cashew Research ,Puttur - 574 202, Karnataka

4. Balogoun, I., Ahoton, L. E., Saidou, A., Bello, D. O., Ezin, V., Amadji, G. L., Ahohuendo, B. C., Babatounde, S., Chougourou, D. C. and Ahanchede, A., 2016. Effect of climatic factors on cashew (Anacardium Occidentale L.) productivity in Benin (West Africa). J. Earth Sci. Clim. Change, 7(1):1-10, doi:10.4172/21577617.1000329.

5. Bezerra, M. A., Lacerda, C. F. D., Enéas Gomes Filho, E. G., Abreu, C. E. B. D. and Prisco, . T., 2007. Physiology of cashew plants grown under adverse Conditions, Braz. J. Plant Physiol., 19(4):449-461.

6. Bhat, M. G., Nagaraja, K. V., \& Rupa, T. R. (2010). Cashew research in India. Journal of Horticultural Sciences, 5(1), 1-16.

7. Bhoomika, H. R., \& Sudha Rani, N. (2018). Problems and Prospects of Cashew Cultivation in India-An Overview. International Journal of Current Microbiology and Applied Sciences, 7(10), 3687-3694. 


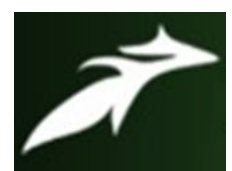

Heli S. Oza et al, International Journal of Advances in Agricultural Science and Technology, Vol.8 Issue.3, March-2021, pg. 27-39

ISSN: 2348-1358

Impact Factor: 6.057

NAAS Rating: 3.77

8. Bhoomika, H. R., \& Sudha Rani, N. (2018). Problems and Prospects of Cashew Cultivation in India-An Overview. International Journal of Current Microbiology and Applied Sciences, 7(10), 3687-3694.

9. Dasmohapatra, R., Rath, S., \& Rout, G. R. (2013). Analysis of genetic relationships in cashew (Anacardium occidentale L.) varieties using morphological characters and ISSR markers. Journal of Plantation Crops (India).

10. Dasmohapatra, R., Rath, S., Pradhan, B., \& Rout, G. R. (2014). Molecular and agro morphological assessment of cashew (Anacardium occidentale L.) genotypes of India. Journal of Applied Horticulture, 16(3).

11. Dendena, B., \& Corsi, S. (2014). Cashew, from seed to market: a review. Agronomy for sustainable development, 34(4), 753-772.

12. Desai A.R., S.P. Singh, J.R. Faleiro, M. Thangam, S. Priya Devi, S.A. Safeena and N.P. Singh (2010). Techniques And Practices For Cashew Production. Technical Bulletin No: 21, ICAR Research Complex for Goa,Ela, Old Goa- 403402, Goa, India

13. Gajbhiye, R. C., Zote, V. K., Bhingarde, R. T. and Haldawaneka,r P. C. (2018) STATUS OF CASHEW RESEARCH AND DEVELOPMENT IN MAHARASHTRA IN: Status of cashew research and development in India: A state perspective (Eds Mohana, G. S. and Nayak, M. G.), A report on the 'All India coordinated research project on cashew', ICAR-Directorate of Cashew Research, Puttur, Karnataka 574 202,India.

14. Gandhi, T., Patel, M., \& Dholakiya, B. K. (2012). Studies on effect of various solvents on extraction of cashew nut shell liquid (CNSL) and isolation of major phenolic constituents from extracted CNSL. Nat. Prod. Plant Resour, 2, 135-142.

15. Ghadage, V. R., Ahlawat, T. R., Chawla, S. L., Shah, N. I., \& Ghadage, N. (2016). Effect of plant growth regulators on flowering behavior of cashew cv. Vengurla-4 grown in the hilly tracts of South Gujarat. Journal of Applied and Natural Science, $8(1), 23-27$.

16. Hanumanthappa, M., Sanganagoud, P. R., Kamath, K. V. S., Vinod, V. R., Dhananjaya, B., \& Shankar, M. (2014). Performance of different cashew (Anacardium occidentale L.) cultivars in coastal Karnataka. Environment and Ecology, 32(3), 891-895.

17. Janani, P., Adiga, J. D., \& Kalaivanan, D. (2020). Effect of Certain Rootstocks on Vegetative, Reproductive Growth and Yield of Cashew Cultivars. Current Journal of Applied Science and Technology, 1-11.

18. Jayasankar, R., Sivapriyan, P.R, \& Muthukumar, R. (2018) STATUS OF HIGH DENSITY CASHEW PLANTING IN TAMIL NADU.

19. Jena, C. and Panda, P. K., 2020. Prospect of cashew cultivation in Odisha: A review. Journal of pharmacognosy and phytochemistry, 9(2):430-433.

20. Kumar, N., Ponnuswami, V., Jeeva, S., Ravindran, C., \& Kalaivanan, D. (2012). Cashew industry in India-An overview. Chronica Horticulturae, 52(1), 23-29.

21. Malhotra, S. K., Hubballi, V. N., \& Nayak, M. G. (2017). Cashew: production, processing, and utilization of by-products. Directorate of Cashewnut and Cocoa Development, Cochin, Kerala, India. 


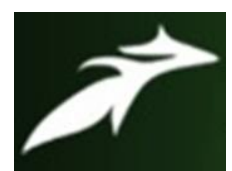

Heli S. Oza et al, International Journal of Advances in Agricultural Science and Technology, Vol.8 Issue.3, March-2021, pg. 27-39

ISSN: 2348-1358

Impact Factor: 6.057

NAAS Rating: 3.77

22. Mall, R. K., Singh, R., Gupta, A., Srinivasan, G., and Rathore, L. S., 2006. Impact of climate change on Indian agriculture: A review. Climate Change, 78:445-478, Doi: 10.1007/s10584-005-9042-x.

23. Mog, B., \& Nayak, M. G. (2018). Leaf morphological and physiological traits and their significance in yield improvement of fifteen cashew varieties in West Coast Region of Karnataka. Int. J. Curr. Microbiol. Appl. Sci, 7, 1455-1469.

24. Muthu Kumar, S., Ponnuswami, V., \& Padmadevi, K. (2011). Cashew industry in India. In I International Symposium on Cashew Nut 1080

25. NAyAk, M. G., MurAlidhArA, B. M., JANAN, P., \& SAvAdi, S. (2020). Performance of cashew (Anacardium occidentale) varieties under different planting density for growth and yield traits. Indian Journal of Agricultural Sciences, 90(8), 1453-1459.

26. Ngatunga, E. L., Cools, N., Dondeyne, S., and Deckers, J. A., 2001. Soil suitability for cashew in South Eastern Tanzania. The Land (2001) 5.1:3-16.

27. Ona AF, Amin M, Emteas MA, Ahmad H, Uddin AFMJ (2017). Performance of eight cashew nut (Anacardium occidentale L.) Germplasm in Bangladesh. Int. J. Bus. Soc. Sci. Res. 5(4):175-182. (http://www.ijbssr.com/currentissueview/14013231).

28. Polisetty, V. V. K., \& Banana, K.(2018) An Economic Analysis of Cashew Industry in India.Vol.-V, Issue -4(4).

29. REJANI, R., RUPA, T., \& NAYAK, M. (2013) Suitability of cashew growing areas in India-an appraisal using GIS.

30. Salam, M. A. and Peter, K. V. (2010). Cashew - A Monograph, Stadium Press (India) Pvt Ltd., New Delhi 110002, India.

31. Saraoj, P. L. (2015). CASHEW CULTIVATION IN INDIA: ISSUES AND CHALLENGES, in CASHEW PRODUCTION TECHNOLOGY.(Eds: Nayak,M.G; Sajeev,M.V)Director ICAR-Directorate of Cashew Research ,Puttur - 574 202, Karnataka

32. Saroj, P. L., Nayak, M. G., \& Meena, R. K. (2014). Physiology of Flowering, Fruit and Nut Development in Cashew. In Eds. Ravishankar, H., Singh, VK, Misra, AK and Mishra, M., Souvenir, National Seminar-cum-workshop on physiology of flowering in perennial fruit crops (pp. 105-114).

33. Sethi, K., Dash, M., \& Tripathy, P. (2020). Character Association and Multivariate Analysis in Cashew (Anacardium occidentale L.). International Journal of Bioresource and Stress Management.

34. Shah, N. I., Sharma, D. K., Makati, J. P., and Parmar, S. G.,( 2018). Status of cashew research and development in Gujarat. IN: Status of cashew research and development in India: A state perspective (Eds Mohana, G. S. and Nayak, M. G.), A report on the 'All India coordinated research project on cashew', ICAR-Directorate of Cashew Research, Puttur, Karnataka 574 202,India.

35. Sreenivas, M., Reddy, M. L., Dorajeerao, A. V. D., \& Paratpararao, M. (2016). FLOWERING PHASES AND THEIR INFLUENCE ON NUT YIELD IN CERTAIN CASHEWNUT HYBRIDS. Plant Archives, 16(1), 317-320. 


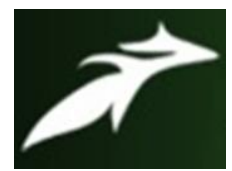

Heli S. Oza et al, International Journal of Advances in Agricultural Science and Technology, Vol.8 Issue.3, March-2021, pg. 27-39

ISSN: 2348-1358

Impact Factor: 6.057

NAAS Rating: 3.77

36. Tola, J. and Mazengia, Y., 2019. Cashew production benefits and opportunities in Ethiopia: A Review. Journal of agricultural and crop research, 7(2):18-25. Doi:10.22495/jacr_v7i2.19.105.

37. Tripathy, P., Sethi, K., \& Mukherjee, S. K. (2015). Evaluation of released cashew varieties under Odisha condition. International Journal of Bio-resource and Stress Management, 6(5), 566-571.

38. Vikram, H. C., Hegde, N. K., \& Jagadeesh, R. C. (2013). Performance of cashew (Anacardium occidentale L.) varieties under northern transition zone of Karnataka. Journal of Plantation Crops (India).

39. Widiatmaka, A. S., Iswandi, A., Daras, U., Hikmat, M. and Krisnohadi, A., 2014. Establishing land suitability criteria for cashew (Anacardium occidentale L.) in Indonesia. Applied and environmental soil science, vol. 2014, Article ID 743194, doi:10.1155/2014/743194. 